\title{
Physicochemical composition and fatty acid profile of milk from F1 Holstein $x$ Zebu cows fed with increasing concentrations of urea
}

\section{Composição físico-química e perfil de ácidos graxos do leite de vacas F1 Holandês x Zebu alimentadas com teores crescentes de ureia}

\author{
Vanice Mendes de Souza ${ }^{1}$; Vicente Ribeiro Rocha Júnior ${ }^{2 *}$; \\ Luciana Albuquerque Caldeira ${ }^{2}$; Ana Paula da Silva Antunes ${ }^{1}$; \\ José Reinaldo Mendes Ruas ${ }^{3}$; Criszoel Ferreira Souza ${ }^{4}$; \\ Ana Cássia Rodrigues de Aguiarr ${ }^{1}$; Dante Pazzanese Duarte Lanna ${ }^{5}$
}

\begin{abstract}
We evaluated the physicochemical composition and fatty acid profile of milk from F1 Holstein $\times$ Zebu cows that were fed increasing levels of urea $(0 \%, 33 \%, 66 \%$ and $100 \%$, corresponding to $0 \%, 0.92 \%$, $1.84 \%$ and $2.77 \%$ CP as NPN) as a substitute for soybean meal. Eight lactating F1 Holstein $\times$ Zebu cows producing an average of $10 \mathrm{~kg}$ of milk per day corrected to $3.5 \%$ fat, were placed in two $4 \times 4$ Latin squares ( 4 animals, 4 diets and 4 periods). Each experimental period lasted 18 days. Milk samples from each cow were collected from morning and afternoon milkings and analyzed for composition and fatty acid concentration. Milk urea nitrogen increased linearly $(\mathrm{P}<0.05)$ with increasing dietary urea. Other variables including fat content, protein, fixed mineral residues, lactose, total nonfat solids, acidity, density, casein, cryoscopic index, somatic cell count, and milk fatty acid concentrations, were not affected by treatment. Thus, urea provides a viable alternative to soybean meal that does not affect the characteristics of milk from primiparous F1 Holstein $\times$ Zebu cows, producing up to $10 \mathrm{~kg}$ of milk corrected to $3.5 \%$ fat day ${ }^{-1}$.
\end{abstract}

Key words: Physicochemical composition, soybean meal, non-protein nitrogen

\section{Resumo}

Objetivou-se avaliar a composição físico-química e o perfil de ácidos graxos do leite de vacas F1 Holandês $\times$ Zebu alimentadas com teores crescentes de ureia $(0 ; 33 \% ; 66 \%$ e $100 \%$, que corresponderam a $0,0,92,1,84$ e $2,77 \%$ de PB na forma de NNP), em substituição ao farelo de soja. Foram utilizadas oito vacas F1 Holandês $\times$ Zebu com produção média de $10 \mathrm{~kg}$ de leite corrigido para 3,5\% de gordura dia $^{-1}$, em duplo quadrados latinos $4 \times 4$ (4 animais, 4 dietas e 4 períodos). Os períodos tiveram dezoito dias. As amostras de leite de cada vaca, da ordenha da manhã e da tarde, foram coletadas e analisadas quanto à composição e a concentração de ácidos graxos. O nitrogênio uréico no leite aumentou linearmente

\footnotetext{
${ }^{1}$ Mestres em Zootecnia pelo Programa de Pós-Graduação em Zootecnia da Universidade Estadual de Montes Claros, UNIMONTES, Campus de Janaúba, MG, Brasil. E-mail: vanicems@yahoo.com.br; anapaula-antunes@hotmail.com; acassiaaguiar@hotmail.com

2 Profs., Dept ${ }^{\circ}$ de Ciências Agrárias, UNIMONTES, Campus de Janaúba, MG, Brasil; Bolsistas de Produtividade em Pesquisa do CNPq e FAPEMIG. E-mail: vicente.rocha@unimontes.br; luburq@yahoo.com.br

${ }^{3}$ Pesquisador, Empresa de Pesquisa Agropecuária de Minas Gerais, EPAMIG, Nova Porterinha, MG, Brasil; Bolsistas de Produtividade em Pesquisa do CNPq. E-mail: jrmruas@epamig.br

${ }^{4}$ Discente do Curso de Mestrado do Programa de Pós-Graduação em Zootecnia, UNIMONTES, Campus de Janaúba, MG, Brasil. E-mail: criszoel@yahoo.com.br

${ }^{5}$ Prof., Universidade Estadual de São Paulo, ESALQ, Campus Piracicaba, SP, Brasil. E-mail: dplanna@usp.br

* Author for correspondence
} 
$(\mathrm{P}<0,05)$ em função dos teores de ureia na dieta. Outras variáveis, incluindo os teores de gordura, proteína, resíduo mineral fixo, lactose, extrato seco total e desengordurado, acidez, densidade, caseína, índice crioscópico, contagem de células somáticas, e a concentração de ácidos graxos do leite, não sofreram efeito dos tratamentos. Portanto conclui-se que a substituição total do farelo de soja pela ureia não influencia composição e nem a concentração de ácidos graxos do leite de vacas primíparas $\mathrm{F} 1$ Holandês $\times$ Zebu, com produção de até $10 \mathrm{~kg}$ de leite corrigido para 3,5\% de gordura dia- 1 .

Palavras-chave: Composição físico-química, farelo de soja, nitrogênio não protéico

\section{Introduction}

The increase in cattle feed prices observed in 2012, specifically regarding soybean meal, led producers to increase the proportion of urea in ruminant diets. Despite an increase in urea prices observed over the past few years, its use is still advantageous when one compares the price per kilogram of gross protein of urea versus that of soybean meal (LIMA FILHO, 2012).

As ruminants, dairy cows rapidly transform non-protein nitrogen (NPN) into ammonia at a lower energetic cost than would be spent by using proteins (AQUINO et al., 2009). Numerous studies have correlated dietary protein supplementation with protein metabolism (HOJMAN et al., 2004), as measured by plasma, blood and milk protein concentrations, with the goal of maximizing the use of dietary nitrogen by dairy cows and improving milk production, processing and quality. NPN intake and use affect the amount of protein and casein in milk, which in turn alters industrial cheese processing (AQUINO et al., 2009).

Several authors have assessed the effects of urea as a substitute for soybean meal in the diets of lactating cows, both on milk production and composition. Aquino et al. (2009) tested increasing percentages of urea in dry matter (DM), and did not find significant effects on the nitrogen fraction and other milk components when using up to $1.5 \%$. These findings suggest that, added to sugar cane, urea provides a viable alternative feed that reduces production costs without altering milk quality. Another study with cows in the final stages of lactation did not find significant effects of $2 \%$ urea in DM on milk production and composition (CARMO et al., 2005). Aguiar et al. (2013) reproduced these results using 7/8 Dutch/Gyr cows. In female goats, however, partial substitution of dietary soybean meal with urea resulted in increased fat and short-chain fatty acid (FA) milk contents (COSTA et al., 2014).

Nutritional manipulation is the most common tool for altering milk composition (NUDDA et al., 2014; OLIVEIRA et al., 2007). Bovine milk contains a large proportion of saturated FA, with four- to 16-carbon chains resulting from de novo synthesis. Some of these FAs are precursors to low-densitylipoprotein (LDL) cholesterol, which increases the risk of cardiovascular disease in humans (NUDDA et al., 2014). According to Benchaar et al. (2007), the ruminal fermentation pattern and ruminal bacteria may alter the FA profile of milk. Thus, the use of increasing levels of NPN in total or partial substitution of true protein in lactating cow diets may alter the ruminal microbiota, the fermentation pattern and, consequently, the contents that reach the duodenum. Part of the FAs in milk comes from the intestinal absorption of lipids, which formerly integrated the membranes of ruminal bacteria (VLAEMINCK et al., 2006). Characterizing the FA composition of milk fat in association to the diet, especially in mixed-breed cows, is a crucial factor for maintaining the quality of products made for human consumption.

Currently, mixed Zebu breeds account for most of the milk produced in Brazil, requiring little technology and low costs (FACÓ et al., 2002). Considering the economic viability of dietary urea for cattle, and given the proportion of Brazilian milk production that depends on mixes of Holstein and Zebu breeds, we evaluated the effects of partial 
and total substitution of soybean meal with urea in the diets of $\mathrm{F} 1$ Holstein $\mathrm{x}$ Zebu cows on the physicochemical composition and FA profile of milk.

\section{Materials and Methods}

Experiments were conducted at the Experimental Farm of the State University of Montes Claros UNIMONTES, in the municipality of Janaúba, state of Minas Gerais, Brazil. The analyses were performed in the Laboratories for Food Analysis and Animal Produce Technology of UNIMONTES, in Janaúba, and in the Clinica do Leite and Animal Nutrition Laboratory at ESALQ-USP, in Piracicaba, state of São Paulo, Brazil.

Experiments included eight primiparous F1 Holstein $x$ Zebu cows, which produced an average of $10 \mathrm{~kg}$ per day of milk corrected for $3.5 \%$ fat. Cows had been lactating for 150 days at the beginning of the experiments. We adopted two four-by-four Latin squares with four animals, four treatments and four experimental periods in each. The four experimental diets substituted soybean meal using different amounts of urea $(0 \%, 33 \%, 66 \%$ and $100 \%)$, which corresponded to $0 \%, 0.92 \% ; 1.84 \%$ and $2.77 \%$ of the gross protein substituted for NPN. The experiment was divided into four 18-day periods, where the first 15 days were used for animal adaptation to the diets, and the last three days were used for the collection of samples and data.

Isoproteic diets were formulated according to the NRC (2001) for cows with an average live weight of $450 \mathrm{~kg}$ and average milk production of $10 \mathrm{~kg}$ per day corrected for $3.5 \%$. Cows were fed these diets twice daily at 08:00 and 16:00 hrs.

Sorghum silage was used as forage, which was weighed daily on a digital scale and distributed to the animals mixed with the concentrate corresponding to each treatment. Leftovers were weighed and recorded. The amount of experimental diet provided to the animals was adjusted so that the amount of leftovers represented $10 \%$ of the total feed, while maintaining the same ratio of forage to concentrate $(80: 20)$ in the DM. Table 1 details the contents and composition of the diets.

Table 1. Ingredients and chemical composition of experimental diets.

\begin{tabular}{lcrrr}
\hline & \multicolumn{3}{c}{ Continue ... } \\
\hline & Ingredients & (\% of dry matter) & & \\
& \multicolumn{2}{c}{ Levels of gross protein substituted with non-protein nitrogen (\%) } \\
\cline { 2 - 5 } Ingredients & 0.00 & 0.92 & 1.84 & 2.77 \\
\hline Sorghum silage & 80 & 80 & 80 & 80 \\
Soybean meal & 6.74 & 4.49 & 2.24 & 0.00 \\
Ground corn & 12.26 & 14.14 & 16.02 & 17.90 \\
Urea : ammonium sulfate (9:1) & 0.00 & 0.36 & 0.73 & 1.1 \\
Mineral supplement & 1 & 1 & 1 & 1 \\
\hline & Chemical composition & & & \\
\hline Dry matter (\%) & 46.72 & 46.71 & 46.67 & 46.05 \\
Organic matter (\%) & 93.28 & 93.31 & 93.4 & 93.54 \\
Gross protein (\%) & 9.84 & 9.86 & 9.89 & 9.92 \\
Acid detergent insoluble nitrogen (\%) & 0.45 & 0.43 & 0.5 & 0.48 \\
Neutral detergent insoluble nitrogen (\%) & 0.025 & 0.024 & 0.028 & 0.027 \\
Ether extract (\%) & 1.84 & 1.85 & 1.86 & 1.86 \\
Total carbohydrates (\%) & 81.61 & 81.43 & 81.25 & 82.05 \\
Non-fibrous carbohydrates (\%) & 27.41 & 27.03 & 27.17 & 27.14 \\
\hline
\end{tabular}




\begin{tabular}{lrrrr}
\multicolumn{1}{c}{} & \multicolumn{2}{c}{... Continuation } \\
\hline Fiber in neutral detergent (FND) (\%) & 55.97 & 55.90 & 55.83 & 55.77 \\
FND corrected for ashes and protein (\%) & 54.20 & 54.40 & 54.08 & 54.91 \\
Fiber in acid detergent (\%) & 31.75 & 31.63 & 31.5 & 31.37 \\
Lignin (\%) & 3.17 & 3.15 & 3.12 & 3.10 \\
Total digestible nutrients (\%) $^{1}$ & 65.0 & 65.58 & 65.18 & 64.68 \\
\hline
\end{tabular}

'NRC (2001).

Animals were milked mechanically, in the presence of the calf, twice daily at 07:30 and at 15:50 hrs. Milk samples were collected from each animal, twice daily during the last three days of each experimental period. Morning and afternoon samples were pooled together following the proportion of milk production in the morning and afternoon. Milk samples were homogenized and the physicochemical characteristics of $500 \mathrm{~mL}$ aliquots were analyzed on the same day. Milk production adjusted for $3.5 \%$ fat was calculated using the equation proposed by Sklan et al. (1994).

The following analyses were performed in triplicate: titratable acidity $\left({ }^{\circ} \mathrm{D}\right)$ measured with phenolphthalein $(0.1 \%)$; $\mathrm{pH}$ using the digital $\mathrm{pH}$ meter Tecnopon; density at $15{ }^{\circ} \mathrm{C}$ using a thermolacto-densitometer type Quevenne; fat contents using the Gerber method; protein contents using the Kjeldahl method and multiplying nitrogen percentage for the factor 6.38; ashes by incineration at $550{ }^{\circ} \mathrm{C}$; and the cryoscopic index $\left({ }^{\circ} \mathrm{H}\right)$ measured with an Laktron 312-L electronic cryoscope. Lactose percentage was calculated from the difference among solid contents (protein, fat and ashes). Total dry extract (TDE) was obtained from the formula $\mathrm{TDE}=1.2 \times$ Fat $+2.665 \times$ (D-1), proposed by Fleishmann, and fat-free dry extract (FDE) resulted from the subtraction of fat content (BRASIL, 2006).

Pooled milk samples from the morning and afternoon of the last day of the experimental period were used for the analyses of urea, casein and somatic cell count (SCC). These samples were conditioned in flasks with the preservative bronopol prior to analyses. Urea nitrogen content and casein percentages were determined by the infrared method - PO ANA 009, and SCC was performed with flow cytometry - PO ANA 008.

The FAs were extracted as described by Hara and Radin (1978), and methylation was performed as described by Christie (1982). Trans-methylated samples were analyzed in a gas chromatograph model Focus CG-Finnigan, with flame ionization detector, $100 \mathrm{~m}$ capillary column CP-Sil 88 , with a diameter of $0.25 \mu \mathrm{m}$ and a film thickness of 0.20 $\mu \mathrm{m}$. Hydrogen was used as carrier gas with a flow of $1.8 \mathrm{ml} / \mathrm{min}$. The program was $70{ }^{\circ} \mathrm{C}$, waiting time $4 \mathrm{~min}, 175^{\circ} \mathrm{C}\left(13{ }^{\circ} \mathrm{C} / \mathrm{min}\right)$, waiting time $27 \mathrm{~min}$, $215^{\circ} \mathrm{C}\left(4^{\circ} \mathrm{C} / \mathrm{min}\right)$, waiting time $9 \mathrm{~min}$, after which the temperature increased $7{ }^{\circ} \mathrm{C} / \mathrm{min}$ up to $230^{\circ} \mathrm{C}$, at which point it was kept for another $5 \mathrm{~min}$, totaling 65 min. Vaporizer temperature was $250{ }^{\circ} \mathrm{C}$ and the detector temperature was $300{ }^{\circ} \mathrm{C}$.

A $1 \mu \mathrm{L}$ aliquot of esterified extract was injected in the chromatograph and FA identification was performed by comparing retention times with standard FAs from butter. FA percentages were obtained with the Chromquest 4.1 software (Thermo Electron, Italy). FAs were quantified by normalization of methyl ester areas. FA contents were expressed in $\mathrm{mg} / \mathrm{g}$ of fat.

The nutritional quality of the lipid fraction was assessed from the FA composition data, according to the following formulae: atherogenicity index $(\mathrm{AI})=\{(\mathrm{C} 12: 0+(4 \mathrm{x} \mathrm{C} 14: 0)+\mathrm{C} 16: 0)\} /\left(\sum \mathrm{AGMI}+\right.$ $\left.\sum \omega 6+\sum \omega 3\right)$; thrombogenicity index $(\mathrm{TI})=(\mathrm{C} 14: 0$ $+\mathrm{C} 16: 0+\mathrm{C} 18: 0) /\left\{\left(0.5 \times \sum \mathrm{AGMI}\right)+\left(0.5 \times \sum \omega 6+\right.\right.$ $\left.\left(3 \times \sum \omega 3\right)+\left(\sum \omega 3 / \sum \omega 6\right)\right\}$; ratio between hyperand hypo-cholesterolemic FAs $(\mathrm{HH})=(\mathrm{C} 14: 0+$ 
C16:0) / (monounsaturated FA + polyunsaturated FA); ratios between PUFA and saturated FA (SFA) and between $\omega 6$ and $\omega 3$, calculated according to Ulbricth and Southage (1991); and nutritionally desirable FA $($ NDFA $)=($ unsaturated FAs + C18:0), calculated according to Costa et al. (2008).

Physicochemical and FA profile as well as nutritional data were subjected to analysis of variance and, when $\mathrm{F}$ was significant, treatment averages were compared with the control diet (without urea) using Dunnett's test with a probability level of $5 \%$. The effects of different levels of dietary urea were assessed by regression with a probability level of 5\%. Analyses were performed with the SAS statistical software (SAS INSTITUTE, 2008). Because SCC represents a discrete quantitative variable resulting from cell counting, data were transformed logarithmically $[\log (\mathrm{X}+1)]$.

\section{Results and Discussion}

Dietary urea as substitute for soybean meal did not affect any of the physicochemical milk variables shown in table 2, with the exception of milk urea nitrogen (MUN). These results suggest that the nutritional requirements of the animals studied were met, especially considering that milk production was similar across treatments, despite the linear increase in MUN with increasing dietary urea. Thus, ruminal microorganisms are probably able to adequately process the changing diets, since other variables (i.e., milk casein) also behaved similarly in all treatment groups. Indeed, previous work using urea as a supplement for pasturing calves did not find variations in ruminal microbe efficiency (MORAES et al., 2009).

Table 2. Milk production corrected for 3.5\% fat, physicochemical composition and somatic cell counts of milk from F1 Holstein $\mathrm{x}$ Zebu cows fed diets with increasing urea concentrations.

\begin{tabular}{|c|c|c|c|c|c|c|c|}
\hline \multirow[t]{2}{*}{ Variables } & \multicolumn{4}{|c|}{$\begin{array}{l}\text { Levels of gross protein substituted for } \\
\text { non-protein nitrogen }(\%)\end{array}$} & \multirow[t]{2}{*}{$\mathrm{CV}(\%)$} & \multirow{2}{*}{$\begin{array}{c}\text { Regression } \\
\text { equation }\end{array}$} & \multirow[t]{2}{*}{$\mathrm{Pr}>\mathrm{Fc}$} \\
\hline & 0.00 & 0.92 & 1.84 & 2.77 & & & \\
\hline Density at $15^{\circ} \mathrm{C}$ & 1.031 & 1.031 & 1.031 & 1.03 & 0.29 & $\hat{\mathrm{Y}}=1.031$ & 0.7861 \\
\hline Cryoscopic index $\left({ }^{\circ} \mathrm{H}\right)$ & -0.541 & -0.542 & -0.540 & -0.543 & -0.96 & $\hat{Y}=-0.542$ & 0.4111 \\
\hline Fat $(\%)$ & 3.47 & 3.68 & 3.46 & 3.48 & 16.01 & $\hat{\mathrm{Y}}=3.52$ & 0.5264 \\
\hline Fat (g/day) & 274.5 & $276.6^{*}$ & $296.4^{*}$ & $304.1^{*}$ & 13.00 & 1 & 0.0456 \\
\hline Protein $(\%)$ & 3.43 & 3.46 & 3.36 & 3.29 & 6.34 & $\hat{\mathrm{Y}}=3.38$ & 0.4035 \\
\hline Protein (g/day) & 266.6 & $275.2^{*}$ & $278.5^{*}$ & $290.9^{*}$ & 9.85 & 2 & 0.0486 \\
\hline Casein $(\%)$ & 2.68 & 2.71 & 2.59 & 2.54 & 2.79 & $\hat{Y}=2.63$ & 0.3440 \\
\hline Casein (\% Total protein) & 77.88 & 78.15 & 77.19 & 76.96 & 1.93 & $\hat{\mathrm{Y}}=77.55$ & 0.3567 \\
\hline Casein/Total protein & 0.76 & 0.78 & 0.78 & 0.78 & 1.64 & $\hat{Y}=0.78$ & 0.3389 \\
\hline Lactose $(\%)$ & 4.74 & 4.67 & 4.72 & 4.85 & 3.2 & $\hat{Y}=4.75$ & 0.1395 \\
\hline Total dry extract (\%) & 14.14 & 14.2 & 13.99 & 13.97 & 7.16 & $\hat{\mathrm{Y}}=14.07$ & 0.9606 \\
\hline Fat-free dry extract (\%) & 9.15 & 9.21 & 9.09 & 9.03 & 3.9 & $\hat{Y}=9.12$ & 0.7583 \\
\hline Fixed mineral residue (\%) & 0.8 & 0.79 & 0.79 & 0.8 & 3.85 & $\hat{\mathrm{Y}}=0.79$ & 0.9893 \\
\hline Milk urea nitrogen (mg/dL) & 7.14 & $8.80 *$ & $11.04 *$ & $11.32 *$ & 13.33 & 3 & 0.0000 \\
\hline Somatic cell count $(\mathrm{x} 1000 / \mathrm{mL})$ & 146.75 & 122.75 & 128.25 & 161.37 & 22.1 & $\hat{\mathrm{Y}}=139.7$ & 0.8746 \\
\hline Fat-correct milk prod. $\left(\mathrm{kg} \mathrm{day}^{-1}\right)$ & 9.97 & 10.36 & 9.93 & 9.92 & 4.99 & $\hat{\mathrm{Y}}=10.05$ & 0.3889 \\
\hline
\end{tabular}

Averages followed by asterisks differ from control ( $0 \%$ urea) by Dunnett's test at $5 \%$ significance. $\mathrm{CV}=$ coefficient of variation. 1 $\mathrm{Y}=271.47+12.056 \mathrm{x}\left(\mathrm{R}^{2}=0.923\right) ; 2 \mathrm{Y}=266.53+7.931 \mathrm{x}\left(\mathrm{R}^{2}=0.951\right) ; 3 \mathrm{Y}=7.515+1.527 \mathrm{x}\left(\mathrm{R}^{2}=0.932\right)$. 
The physicochemical characteristics of milk found here (Table 2) lie within the ranges recommended in guideline number 62 (BRASIL, 2011). This finding suggests that partial or total substitution of soybean meal with urea in the diets of primiparous F1 Holstein x Zebu cows should not affect milk processing by the dairy industry. Milk density and cryoscopic index were not affected by the different urea concentrations, and treatment averages were $1.031 \mathrm{~g} / \mathrm{ml}$ and $-0.542{ }^{\circ} \mathrm{H}$, respectively.

Milk fat content was similar among treatments (Table 2) and above the minimum level of 3.0\% for whole milk. However, milk fat production expressed in $\mathrm{g} /$ day was affected $(\mathrm{p}<0.05)$ by dietary urea increasing linearly from 274.5 to $304.1 \mathrm{~g} /$ day, despite the similar levels of milk production across treatments. The observed adequate fat content may result from the genetics of the animals derived from pure breed Holstein and Zebu, which are associated with elevated diet fibers provided by the $80: 20$ ratio of forage to concentrate, which increases the ratio of acetate:propionate in the rumen, and consequently elevates the concentration of fat precursors available to the mammary gland. The linear increase in fat production may result from the variation in milk production.

Similarly to what we observed for fat content, dietary treatments did not affect percentage milk protein. However, milk protein production expressed in $\mathrm{g}$ /day increased $(\mathrm{P}<0.05)$ linearly with urea in the diet, varying between 266.6 and 290.9 $\mathrm{g} /$ day. This finding may be explained by improved ruminal efficiency for the production of protein from ammonium nitrogen. The high proportion of forage in diets increases the numbers of bacteria that ferment fibrous carbohydrates in the rumen, and these microorganisms only use ammonium nitrogen for growth.

In the present study, casein concentrations, casein as a percentage of total milk protein, and the casein : total protein ratio were not affected by the different levels of dietary urea, despite the increase in MUN. Thus, substituting soybean meal with urea did not limit the production of this protein by the mammary gland. The fact that ruminal microorganisms convert NPN into protein of high biological value may explain this finding. Milk casein plays a crucial role in cheese production (AQUINO et al., 2009).

Milk lactose content was not affected by diet, which was expected because of its important role in maintaining the osmotic balance of milk. We found levels of lactose ranging between $4.6 \%$ and $4.85 \%$, which are considered normal for bovine milk.

The TDE, FDE and fixed mineral residues did not change with diet. Increasing levels of TDE improve the yield of dairy products. The average TDE of $14.07 \%$ was higher than previously reported. Aquino et al. (2009), for example, assessed the effects of substituting soybean meal with increasing amounts of urea in dairy cow diets on frescal cheese yield and found $11.73 \%$ of TDE in milk. In addition, Saran Netto et al. (2011) evaluated the effects of partially substituting soybean meal with urea in the diets of Girolando cows in a semi-confinement system using Brachiaria decumbens pastures. These authors found TDE levels of $13.81 \%$.

Levels of MUN increased with increasing dietary urea from 7.14 to $11.32 \mathrm{mg} / \mathrm{dL}$. Elevated urea intake probably resulted in higher levels of ammonia in the rumen, as well as greater absorption of ammonia into the blood and milk. According to Roseler et al. (1993), blood urea has low molecular weight and crosses the alveolar epithelium of the mammary gland, thus partitioning into the milk. Chizzotti et al. (2007) found a high correlation between MUN and plasma urea nitrogen (PUN).

Even the highest MUN levels of 11.04 and 11.32 $\mathrm{mg} / \mathrm{dL}$ found in milk from cows fed diets with $66 \%$ and $100 \%$ soybean meal substitution remained within the recommended range for lactating cows of 10 to $16 \mathrm{mg} / \mathrm{dL}$. This finding may explain why an increase in MUN did not parallel changes in milk casein contents. In contrast to our work, 
Souza et al. (2010) did not find altered MUN levels when analyzing the effects of partial soybean meal substitution with a protected source of urea.

We conducted the SCC to monitor for subclinical mastitis in the cows used during the study, as this could affect milk production and composition, and found that it was below 200,000 cells/mL in every treatment and did not differ among treatments. Verdi et al. (1987) assessed milk composition in several herds during a period of two years and a $1 \%$ to $2 \%$ reduction in the ratio of casein to total protein when SCC was high. Reduced casein, in these cases, may reflect reduced synthesis and secretion resulting from damage to the secreting epithelia caused by bacterial toxins. In fact, the action of these toxins also increases the concentration of serum protein in the milk during mastitis, especially albumin and immunoglobulin (PAAPE et al., 1995). Thus, even though some controversy may exist regarding the effects of mastitis on the absolute concentration of casein, the ratio of casein to total protein does decrease as SCC increases (PULINA et al., 2006).

The scientific community has shown increasing interest in the chemical composition and FA profile of milk, as both may affect human health. Likewise, the FA profile allows for an assessment of nutritional lipid quality, which is reflected in the amounts of SFA, MUFA, and PUFA, as well as the percentage of $\omega 6$ and $\omega 3$ FAs. Table 3 shows the concentration of FAs in total milk lipids. No changes were observed with the different treatments. According to Benchaar et al. (2007), changes to ruminal fermentation and microbiota can affect milk FA profile. Thus, alterations to the nitrogen fraction of the diet could alter the proportion of ruminal bacterial species contributing to changes in the FAs that reach the duodenum for absorption. Bacteria that ferment fibrous carbohydrates depend on ammonia for growth, whereas bacteria that ferment non-fibrous carbohydrates use, in addition to ammonia, amino acids and peptides, favoring growth in the presence of the latter two. However, at the production level evaluated of $10 \mathrm{~kg}$ of milk per day (Table 1), soybean meal substitution did not significantly alter bacterial populations in the rumen.

The SFA accounted for $75.17 \%$ of total FA, and the more prevalent forms were palmitic acid (C16:0) $37.65 \%$ and myristic acid (C14:0) 12.58\%. These FAs have hypercholesterolemic action, as they do not activate hepatic LDL receptors, increasing plasma LDL. Elevated LDL may predispose humans to coronary disease, Alzheimer's disease and cancer, among other conditions. However, recent work assessing the effects of dietary FAs on the secondary prevention of coronary disease found no risk reduction with the substitution of SFA for PUFA (SCHWINGSHACKL; HOFFMANN, 2014).

Stearic acid (C18:0) was another SFA present in relatively high amounts in milk fat $(8.49 \%)$. This FA has no effects on circulating LDL levels (SOFI et al., 2010). Oleic acid (C18:1 C9) represented 15.84 points of the total MUFA percentage of $22.29 \%$ and has hypocholesterolemic effects in humans (SOFI et al., 2010).

Table 3 shows that linoleic acid C18:2 C9 C12) represented $1.21 \%$ of total FAs on average, constituting the predominant PUFA, which accounted for $2.13 \%$ of FAs. Elevating PUFA in different foods may have benefits, as these acids serve as precursors to the endogenous synthesis of CLA, which has anti-carcinogenic properties in addition to reducing the incidence of coronary disease, atherosclerosis and breast cancer (NUDDA et al., 2014). In the present study, the prevalent CLA isomer was C18:2 cis-9 trans-11, which improves the nutraceutical properties of milk. 
Table 3. Fatty acid concentration in milk fat from F1 Holstein x Zebu cows fed diets with increasing urea concentrations.

\begin{tabular}{|c|c|c|c|c|c|c|c|}
\hline \multirow{3}{*}{ Fatty acids } & \multicolumn{4}{|c|}{$\begin{array}{l}\text { Levels of gross protein substituted for non- } \\
\text { protein nitrogen }(\%)\end{array}$} & \multirow{3}{*}{ CV $(\%)$} & \multirow{3}{*}{$\hat{\mathrm{Y}}$} & \multirow{3}{*}{$\operatorname{Pr}>\mathrm{Fc}$} \\
\hline & 0.00 & 0.92 & 1.84 & 2.77 & & & \\
\hline & \multicolumn{4}{|c|}{$\mathrm{mg} / \mathrm{g}$ of fat } & & & \\
\hline Saturated & 75.36 & 73.95 & 75.68 & 75.7 & 3.06 & 75.17 & 0.3933 \\
\hline $\mathrm{C} 4: 0$ & 2.74 & 2.74 & 2.75 & 2.92 & 5.44 & 2.79 & 0.0746 \\
\hline C6:0 & 2.11 & 2.08 & 2.13 & 2.28 & 7.8 & 2.15 & 0.1153 \\
\hline C8:0 & 1.23 & 1.22 & 1.2 & 1.33 & 10.7 & 1.28 & 0.1313 \\
\hline C10:0 & 2.87 & 2.74 & 2.87 & 2.2 & 17.52 & 2.92 & 0.3486 \\
\hline $\mathrm{C} 12: 0$ & 3.73 & 3.59 & 3.85 & 4.28 & 16.46 & 3.86 & 0.1833 \\
\hline C14:0 & 12.23 & 12.21 & 12.35 & 13.54 & 7.72 & 12.58 & 0.0648 \\
\hline C15:0 & 0.94 & 1.04 & 1.12 & 0.94 & 24.08 & 1.01 & 0.3933 \\
\hline C16:0 & 38.68 & 37.36 & 38.53 & 36.03 & 7.19 & 37.65 & 0.2141 \\
\hline C17:0 & 0.55 & 0.57 & 0.56 & 0.58 & 5.48 & 0.56 & 0.2068 \\
\hline C18:0 & 8.64 & 8.47 & 8.35 & 8.5 & 8.43 & 8.49 & 0.8809 \\
\hline $\mathrm{C} 24: 0$ & 0.07 & 0.07 & 0.06 & 0.07 & 28.46 & 0.07 & 0.8047 \\
\hline Monounsaturated & 21.96 & 23.42 & 21.85 & 21.95 & 9.3 & 22.29 & 0.3910 \\
\hline C16:1 C9 & 1.89 & 1.97 & 2.00 & 1.94 & 10.43 & 1.95 & 0.7328 \\
\hline C18:1 T10-T11-T12 & 0.68 & 0.68 & 0.68 & 0.68 & 0.00 & 0.68 & 0.1011 \\
\hline C18:1 C9 & 15.59 & 16.82 & 15.41 & 15.55 & 10.57 & 15.84 & 0.3273 \\
\hline C18:1 C11 & 1.14 & 1.27 & 1.15 & 1.09 & 17.04 & 1.16 & 0.3322 \\
\hline Polyunsaturated & 2.26 & 2.27 & 2.01 & 1.95 & 11.55 & 2.13 & 0.0609 \\
\hline C18:2 C9 C12 & 1.28 & 1.29 & 1.17 & 1.09 & 11.67 & 1.21 & 0.0625 \\
\hline $\mathrm{C} 18: 3 \mathrm{w} 3$ & 0.39 & 0.43 & 0.37 & 0.37 & 14.41 & 0.39 & 0.1409 \\
\hline C18:2 C9 T11(CLA) & 0.27 & 0.3 & 0.25 & 0.27 & 19.17 & 0.28 & 0.2904 \\
\hline
\end{tabular}

Averages followed by asterisks differ from control ( $0 \%$ urea) by Dunnett's test at $5 \%$ significance. $\mathrm{CV}=$ coefficient of variation. CLA = conjugated linoleic acid.

The substitution of soybean meal with urea had no effect on the nutritional quality of the lipid profile (Table 4). We found average values for AI and TI of 4.10 and 5.17, respectively. No guidelines currently exist regarding the AI and TI of dairy products, and lower indices are thought to be better for human health (SOUSA BENTES et al., 2009). According to Turan et al. (2007), higher AI and TI promote platelet aggregation, whereas lower AI and TI translate into more anti-atherogenic FAs and better disease prevention profiles.

The hyper/hypocholesterol $(\mathrm{HH})$ ratio is an index that takes into account the functional activity of FAs in the metabolism of plasma cholesterol lipoproteins, whose types and quantities are associated with higher or lower risk of cardiovascular disease. There are no recommended $\mathrm{HH}$ values for dairy products. However, the value of 2.0 used for meats can be taken as a reference. From a nutritional aspect, values lower than 2.0 provide a better FA profile and reduce the risk of cardiovascular disease (SANTOS-SILVA et al., 2002). Here we found an average $\mathrm{HH}$ of 2.09 , indicating that the milk from Holstein x Zebu cows has a near-ideal FA profile.

A PUFA/SFA ratio below 0.45 is considered unhealthy for its potential to increase plasma cholesterol. We found an average value of 0.03 . Nevertheless, we found an average $\omega 6 / \omega 3$ ratio of 16.25 , which is above the recommended value of 4.0 (HAUG et al., 2007; MARTIN et al., 2006). 
Table 4. Atherogenicity index, thrombogenicity index, hyper/hypocholesterolemic fat ratio, nutritionally desirable fatty acids, PUFA/SFA ratio and $\omega 6 / \omega 3$ ratio in milk from F1 Holstein x Zebu cows fed diets with increasing urea concentrations.

\begin{tabular}{|c|c|c|c|c|c|c|c|}
\hline \multirow[t]{2}{*}{ Variables } & \multicolumn{4}{|c|}{$\begin{array}{l}\text { Levels of gross protein substituted for non- } \\
\text { protein nitrogen }(\%)\end{array}$} & \multirow[t]{2}{*}{ CV (\%) } & \multirow[t]{2}{*}{$\hat{\mathrm{Y}}$} & \multirow[t]{2}{*}{$\operatorname{Pr}>\mathrm{Fc}$} \\
\hline & 0.00 & 0.92 & 1.84 & 2.77 & & & \\
\hline Atherogenicity index ${ }^{1}$ & 4.18 & 3.77 & 4.16 & 4.27 & 14.24 & 4.1 & 0.3542 \\
\hline Thrombogenicity index ${ }^{2}$ & 5.38 & 4.81 & 5.31 & 5.19 & 12.58 & 5.17 & 0.3353 \\
\hline Hyper/Hypocholesterolemic ${ }^{3}$ & 2.16 & 1.94 & 2.15 & 2.1 & 13.87 & 2.09 & 0.4081 \\
\hline Desirable FAs ${ }^{4}$ & 32.79 & 34.16 & 32.21 & 32.44 & 7.77 & 32.9 & 0.4451 \\
\hline PUFA/SFA & 0.03 & 0.03 & 0.03 & 0.03 & 13.54 & 0.03 & 0.0687 \\
\hline G6/033 & 16.95 & 17.76 & 16.04 & 14.25 & 30.69 & 16.25 & 0.1744 \\
\hline
\end{tabular}

Averages followed by asterisks differ from control ( $0 \%$ urea) by t's test at $5 \%$ significance. $\mathrm{CV}=$ coefficient of variation. PUFA/SFA $=$ ratio of polyunsaturated to saturated fatty acids. $\omega 6 / \omega 3=$ ratio of Ômega- 6 to Ômega- 3 fatty acids (ULBRICTH; SOUTHAGE, 1991). ${ }^{1}\{(\mathrm{C} 12: 0+(4 \times \mathrm{C} 14: 0)+\mathrm{C} 16: 0)\} /\left(\sum\right.$ AGMI $\left.\left.\left.+\sum \omega 6+\sum \omega 3\right)\right)\right\}$ (ULBRICTH; SOUTHAGE, 1991); ${ }^{2}(\mathrm{C} 14: 0+\mathrm{C} 16: 0+\mathrm{C} 18: 0) /\left\{\left(0,5 \times \sum\right.\right.$ AGMI $)+\left(0,5 \times \sum \omega 6+\left(3 \times \sum \omega 3\right)+\left(\sum \omega 3\right.\right.$ / $\left.\left.\sum \omega 6\right)\right\}\left(\right.$ ULBRICTH; SOUTHAGE, 1991); ${ }^{3}(\mathrm{C} 14: 0+\mathrm{C} 16: 0) /($ monounsaturated + polyunsaturated) (ULBRICTH; SOUTHAGE, 1991); ${ }^{4}$ (unsaturated+C18:0) (COSTA et al., 2008).

The total substitution of soybean meal with urea in the diets of F1 Holstein $\mathrm{x}$ Zebu cows producing $10 \mathrm{~kg}$ of milk per day corrected for 3.5\% fat does not alter the physicochemical composition or FA profile of milk.

\section{Acknowledgments}

We thank FAPEMIG for financial support as well as CNPq and CAPES for scholarships. We also thank INCT-Ciência Animal.

\section{References}

AGUIAR,A. C. R. de; OLIVERIA, C. R.; CALDEIRA, L. A.; ROCHA JÚNIOR, V. R.; OLIVEIRA, S. J.; SOARES, C.; SILVA, D. A.; MENEZES, J. C. de; BORGES, L. D. A. Consumo, produção e composição do leite e do queijo de vacas alimentadas com níveis crescentes de ureia. Revista Brasileira de Ciência Veterinária, Niterói, v. 20, n. 1, p. 37-42, 2013.

AQUINO, A. A.; PEIXOTO, K. C.; GIGANTE, M. L.; RENNO, F. P.; PRADA e SILVA, L. F.; SANTOS, M. V. Efeito de níveis crescentes de uréia na dieta de vacas leiteiras sobre a composição e rendimento de fabricação de queijos Minas frescal. Brazilian Jornal of Veterinary Research and Animal Science, São Paulo, v. 46, n. 4, p. 273-279, 2009.

BENCHAAR, C.; PETIT, H. V.; BERTHIAUME, R.; OUELLET, D. R.; CHIQUETTE, J.; CHOUINARD, P. Y. Effects of essential oils on digestion, ruminal fermentation, rumen microbial populations, milk production, and milk composition in dairy cows fed alfalfa silage or corn silage. Journal of Dairy Science, Champaign, v. 90, n. 2, p. 886-897, 2007.

BRASIL. Ministério da Agricultura, Pecuária e Abastecimento. Instrução Normativa $n^{\circ} .68$ de 12 de dezembro de 2006. Métodos analíticos oficiais físicoquímicos para controle de leite e produtos lácteos. Diário Oficial [da] União, Brasília, DF, 2006. Seção 1, p. 8. Disponível em: $<$ http://www.agricultura.gov.br $>$. Acesso em: 18 fev. 2014.

. Instrução Normativa $n^{\circ} 62$, de 29 de dezembro de 2011. Aprova o regulamento técnico de produção, identidade e qualidade do leite tipo a, o regulamento técnico de identidade e qualidade de leite cru refrigerado, o regulamento técnico de identidade e qualidade de leite pasteurizado e o regulamento técnico da coleta de leite cru refrigerado e seu transporte a granel, em conformidade com os Anexos desta Instrução Normativa. Diário Oficial [da] União, Brasília, DF, 2011. Seção 1, p. 6. Disponível em: <http://www.agricultura. gov.br>. Acesso em: 18 fev. 2014. 
CARMO, C. A.; SANTOS, F. A. P.; IMAIZUMI, H. Substituição do farelo de soja por ureia ou amireia para vacas em final de lactação. Acta Scientiarum Agronomy, Maringá, v. 27, n. 2, p. 277-286, 2005.

CHIZZOTTI, M. L.; VALADARES FILHO, S. C.; VALADARES R. F. D.; CHIZZOTTI F. H. M.; MARCONDES M. I.; FONSECA M. A. Intake, digestibility and nitrogen metabolism in holstein cows with different milk production levels. Revista Brasileira de Zootecnia, Viçosa, MG, v. 36, n. 1, p. 138-146, 2007.

CHRISTIE, W. W. A simple procedure for rapid transmethilation of glycerolipids and cholesterol esters. Journal of Lipid Research, Rockville, v. 23, n. 7, p. 10721975, 1982.

COSTA, R. G.; BARBOSA, J. G.; QUEIROGA, R. C. R. E.; MEDEIROS, A. N.; CARVALHO, M. G. X.; BELTRÃO FILHO, E. M. Production and quality of Alpine goat milk by using urea in place of soybean meal. Semina: Ciências Agrárias, Londrina, v. 35, n. 6, p. 3263-3272, 2014.

COSTA, R. G.; MESQUITA, I. V. U.; QUEIROGA, R. C. R. E.; MEDEIROS, A. N.; CARVALHO, F. F. R.; BELTRÃO FILHO, E. M. Características químicas e sensoriais do leite de cabras Moxotó alimentadas com silagem de maniçoba. Revista Brasileira de Zootecnia, Viçosa, MG, v. 37, n. 4, p. 694-702, 2008.

FACÓ, O.; LÔBO, R. N. B.; MARTINS FILHO, R.; MOURA, A. A. A. Análise do desempenho produtivo de diversos grupos genéticos Holandês x Gir no Brasil. Revista Brasileira de Zootecnia, Viçosa, MG, v. 31, n. 5, p. 1944-1952, 2002.

HARA, A.; RADIN, N. S. Lipid extraciton of tissues with lowtoxicity solvent. Analitical Biochemistry, Bethesda, v. 90, n. 1, p. 420-426, 1978.

HAUG, A.; HØSTMARK, A. T.; HARSTAD, O. M. Bovine milk in human nutrition - a review. Lipids in Health and Disease, London, v. 6, n. 25, p. 25-40, 2007.

HOJMAN, D. Relationships between milk urea and production, nutrition and fertility traits in Israeli dairy herds. Journal of Dairy Science, Champaign, v. 87, n. 4, p. 1001-1011, 2004.

LIMA FILHO, R. R. Alta de preço da ureia pecuária. [S.1.: s.n.], 2012. Disponível em: <http://www.scotconsultoria. com.br/noticias/todas-noticias/25689/alta-de-preco-daureia-pecuaria.htm>. Acesso: 30 mar. 2013.

MARTIN, C. A.; ALMEIDA, V. V.; RUIZ, M. R.; VISENTAINER, J. E. L.; MATSHUSHITA, M.; SOUZA, N. E.; VISENTAINER, J. V. Ácidos graxos poliinsaturados ômega-3 e ômega-6: importância e ocorrência em alimentos. Revista Nutrição, Campinas, v. 19, n. 6, p. 761-770, 2006.

MORAES, E. H. B. K.; PAULINO, M. F.; MORAES, K. A. K.; VALADARES FILHO, S. C.; ZERVOUDAKIS, J. T.; DETMANN, E. Ureia em suplementos proteicoenergéticos para bovinos de corte durante o período da seca: características nutricionais e ruminais. Revista Brasileira de Zootecnia, Viçosa, MG, v. 38, n. 4, p. 770777, 2009.

NATIONAL RESEARCH COUNCIL - NRC. Nutrient requeriments of dairy cattle. $7^{\text {th }}$ ed. Washington, DC: National Academy Press, 2001. 381 p.

NUDDA, A.; BATTACONE, G.; BOAVENTURA NETO, O.; CANNAS, A.; FRACESCONI, A. H. D.; ATIZORI, A. S.; PULINA, G. Feeding strategies to design the fatty acid profile of sheep milk and cheese. Revista Brasileira Zootecnia, Viçosa, MG, v. 43, n. 8, p. 445-456, 2014.

OLIVEIRA, M. A.; REIS, R. B.; LADEIRA, M. M.; PEREIRA, I. G.; FRANCO, G. L.; SATURNINO, H. M.; COELHO, S. G.; ARTUNDUAGA, M. A. T.; FARIA, B. N.; SOUZA JÚNIOR, J. A. Produção e composição do leite de vacas alimentadas com dietas com diferentes proporções de forragem e teores de lipídeos. Arquivo Brasileiro de Medicina Veterinária e Zootecnia, Belo Horizonte, v. 59, n. 3, p. 759-766, 2007.

PAAPE, M. J.; CAPUCO, A. V.; GUIDRY, A. J. Morphology, function and adaptation of mammary cells in normal and disease states. Journal of Animal Science, Champaign, v. 73, n. 2, p. 1-17, 1995.

PULINA, G.; NUDDA, A.; BATTACONE, G.; CANNAS, A. Effects of nutrition on the contents of fat, protein, somatic cells, aromatic compounds, and undesirable substances in sheep milk. Animal Feed Science and Technology, v. 131, n. 3-4, p. 255-291, 2006.

ROSELER, D. K.; FERGUSON, J. D.; SNIFFEN, C. J.; HERREMA, J. Dietary protein degradability effects on plasma and milk urea nitrogen and milk nonprotein nitrogen in Holstein cows. Journal Dairy Science, Champaign, v. 76, n. 2, p. 525-534, 1993.

SANTOS-SILVA, J.; BESSA, R. J. B.; SANTOS-SILVA, F. Effect of genotype, feeding system and slaughter weight on the quality of light lambs: Fatty and composition of meat. Livestock Production Science, Roma, v. 77, n. 2, p. 187-194, 2002.

SARAN NETTO, A.; BARCELOS, B.; CONTI, R. M. C. Substituição parcial de farelo de soja por ureia na alimentação de vacas Girolanda em lactação. Journal of the Health Sciences Institute, São Paulo, v. 29, n. 2, p. 139-142, 2011. 
SCHWINGSHACKL, L.; HOFFMANN, G. Dietary fatty acids in the secondary prevention of coronary heart disease: a systematic review, meta-analysis and metaregression. BMJ Open, London, v. 4, n. 4, p. 1-9, 2014. Disponível em: $<$ http://bmjopen.bmj.com>. Acesso em: 30 jun. 2015.

SKLAN, D. R.; ASHKENAZI, A.; BRAUN, A.; DEVORIN, A.; TEBORI, K. Fatty acids, calcium soaps of fatty acids, and cottonseeds fed to high yielding cows. Journal of Dairy Science, Champaign, v. 75, n. 9, p. 2463-2472, 1994.

SOFI, F.; BUCCIONI, A.; CESARI, F.; GORI, A. M.; MINIERI, S.; MANNINI, L.; CASINI, A.; GENSINI, G. F.; ABBATE, R.; ANTONGIOVANNI, M. Effects of a dairy product (pecorino cheese) naturally rich in cis-9, trans-11 conjugated linoleic acid on lipid, inflammatory and haemorheological variables: a dietary intervention study. Nutrition, Metabolism and Cardiovascular Diseases, Roma, v. 20, n. 2, p. 117124, 2010.

SOUSABENTES, A.; SOUZA, H. A. L.; SIMÕES, M. G.; MENDONÇA, X. M. F. Caracterização física e química e perfil lipídico de três espécies de peixes amazônicos. Revista Brasileira de Tecnologia Agroindustrial, Ponta Grossa, v. 3, n. 2, p. 97-108, 2009.
SOUZA, V. L.; ALMEIDA, R.; SILVA, D. F. F.; PIEKARSKI, P. R. B.; JESUS, C. P.; PEREIRA, M. N. Substituição parcial de farelo de soja por ureia protegida na produção e composição do leite. Arquivo Brasileiro de Medicina Veterinária e Zootecnia, Belo Horizonte, v. 62, n. 6, p. 1415-1422, 2010.

STATISTICAL ANALISYS SYSTEM - SAS. System for microsoft windows. OnlineDoc ${ }^{\circledR}$ for Windows 9. 2. Cary: Statistical Analysis System Institute, 2008.

TURAN, H.; SÖNMEZ, G.; KAYA, Y. Fatty acid profi le and proximate composition of the thornback ray (Raja clavata, L. 1758) from the Sinop coast in the Black Sea. Journal Fish Science, Dongcheng, v. 1. n. 2, p. 97-103, 2007.

ULBRICTH, T. L. V.; SOUTHAGE, D. A. T. Coronary heart disease: seven dietary factors. Lancet, London, v. 338, n. 8773, p. 985-992, 1991.

VERDI, R. J.; BARBANO, D. M.; DELLAVALLE, M. E.; SENYK, G. F. Variability in true protein, casein, nonprotein nitrogen, and proteoly sis in high and low somatic cell milks. Journal of Dairy Science, Champaign, v. 70, n. 2, p. 230-242. 1987.

VLAEMINCK, B.; FIEVEZ, V.; TAMMINGA, S.; DEWHURST, R. J.; VAN VUUREN, A.; BRABANDER, D. de; DEMEYER, D. Milk odd- and branched-chain fatty acids in relation to the rumen fermentation pattern. Journal of Dairy Science, Champaign, v. 89, n. 10, p. 3954-3964, 2006. 
